
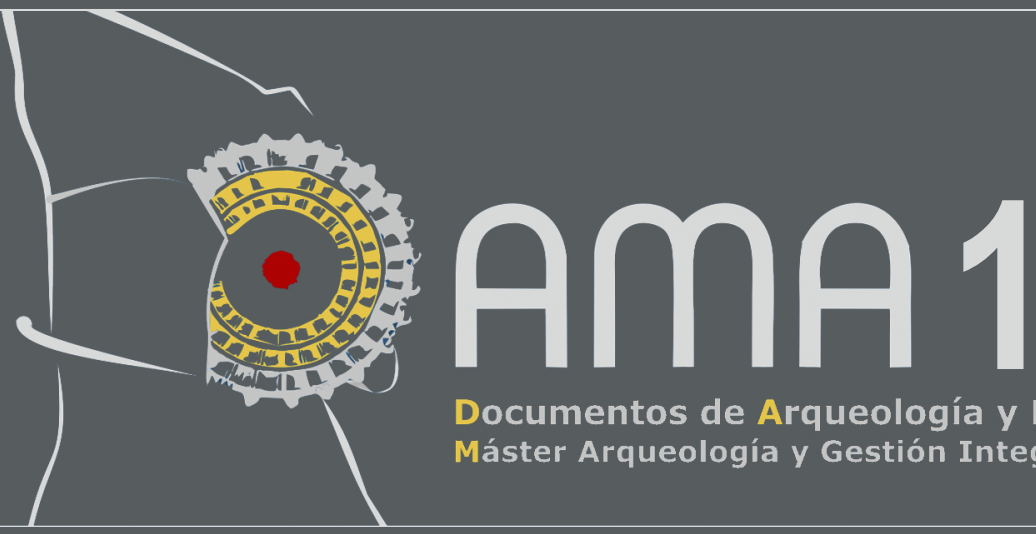

Documentos de Arqueología y Patrimonio Histórico

Máster Arqueología y Gestión Integral del Patrimonio de la Universidad de Alicante

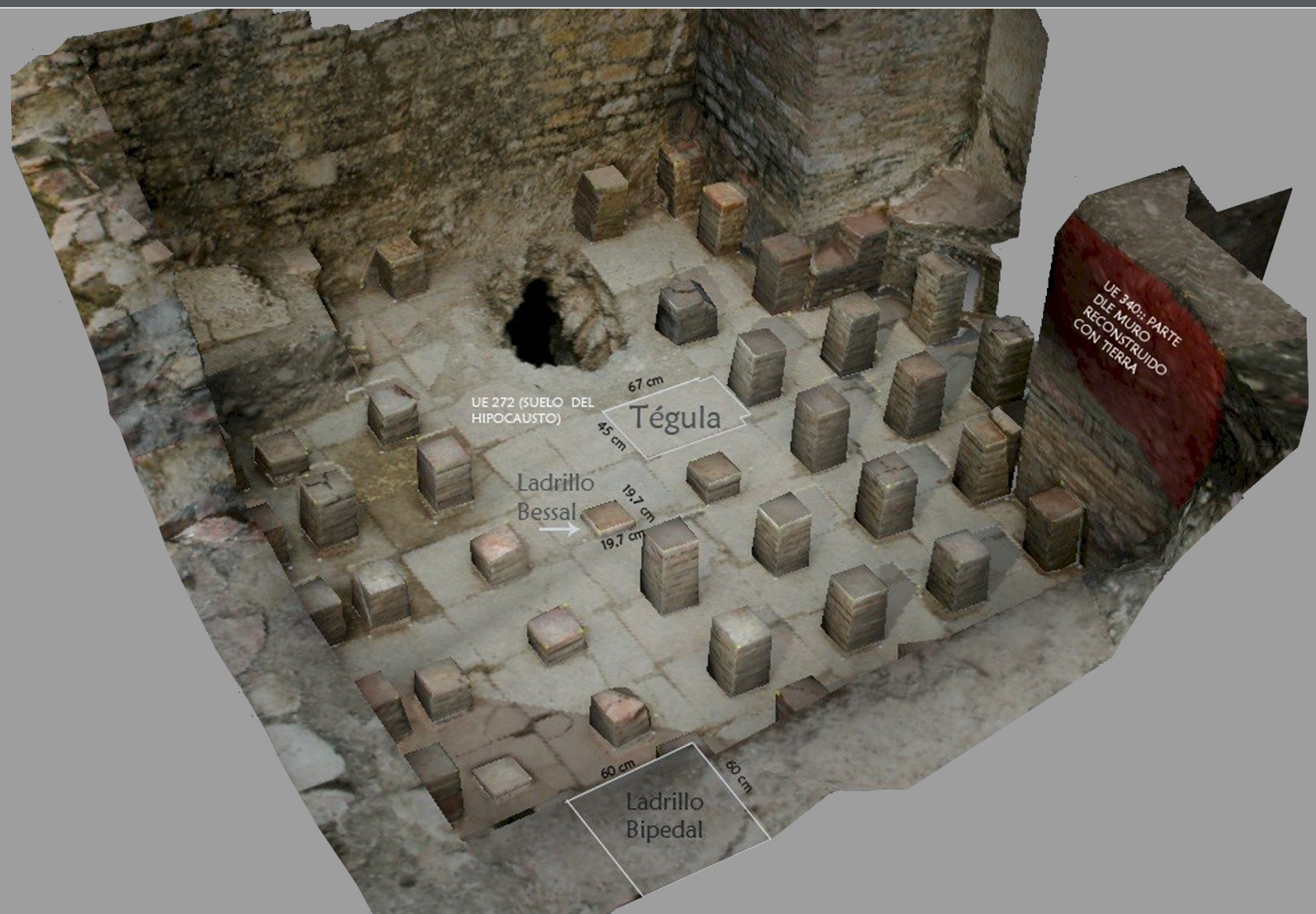

Documentos de Arqueología y Patrimonio Histórico Revista del Máster Universitario en Arqueología Profesional y Gestión integral del Patrimonio 



\section{DAMA 1}

\section{6}

DOCUMENTOS DE ARQUEOLOGÍA Y PATRIMONIO HISTÓRICO DEL MÁSTER UNIVERSITARIO EN ARQUEOLOGÍA PROFESIONAL Y GESTIÓN INTEGRAL DEL PATRIMONIO DE LA UNIVERSIDAD DE ALICANTE 


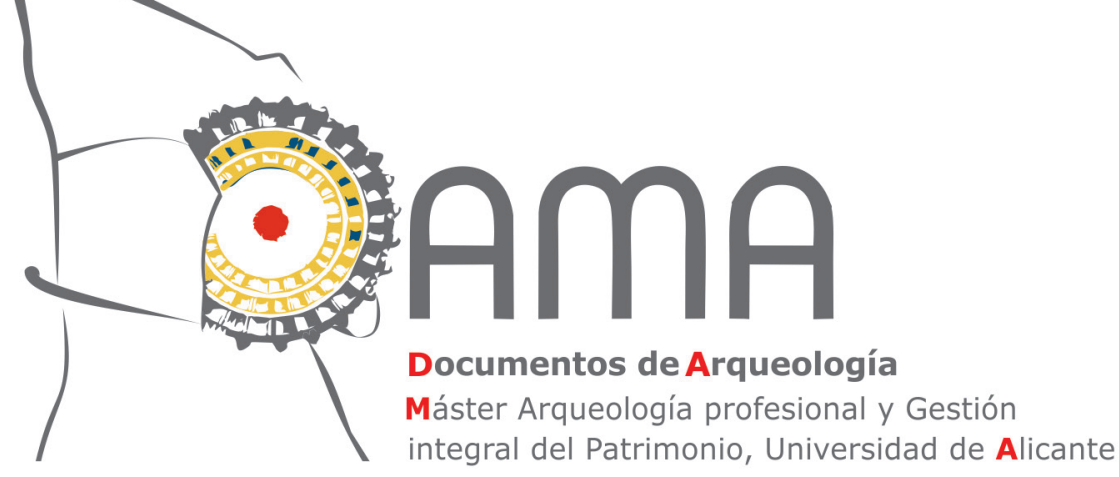

La revista electrónica DAMA. Documentos de Arqueología y Patrimonio Histórico surge como servicio para todos aquellos alumnos del Máster en Arqueología Profesional y Gestión Integral del Patrimonio de la Universidad de Alicante que se están iniciando en la investigación y cuya primera aportación a nuestra disciplina suele ser su Trabajo de Fin de Máster (TFM). Estos proyectos en muchos casos representan casi todo un curso de trabajo y esfuerzo, y con frecuencia quedan inéditos.

El objetivo de esta revista es ofrecer un medio que facilite la publicación de los resultados de sus TFM. La edición se presenta en versión digital y cuenta con su correspondiente ISSN. Se publica de forma anual en el sitio web de la Universidad de Alicante (http://web.ua.es/es/dama/) y en su repositorio (RUA). Los artículos publicados son descargables en formato PDF.

\section{Consejo de Redacción}

Directores (Coordinadores del Máster)

Carolina Doménech Belda

Fernando Prados Martínez

\section{Secretaria de Edición}

Julia Sarabia Bautista

\section{Vocales}

Los miembros de la Comisión Académica del Máster Universitario en Arqueología Profesional y Gestión del Patrimonio (http://dprha.ua.es/es/magip/comision-academica.html)

\section{Edita}

Máster Universitario en Arqueología Profesional y Gestión Integral del Patrimonio Departamento de Prehistoria, Arqueología, Historia Antigua, Filología Griega y Filología Latina

Facultad de Filosofía y Letras II

Universidad de Alicante

Ctra San Vicente del Raspeig s/n

E-03690 San Vicente del Raspeig (Alicante)

Web:http://dprha.ua.es

Teléfono: (+34) 965903663

Fax: (+34) 965903823

E-mail: revista.dama@ua.es

\section{ISSN}

$2530-2345$

\section{Portada}

Modelo fotogramétrico de un hypocaustum romano realizado por Ana Charquero 
EDITORIAL

Coordinación del máster

ENTREVISTA A SOLVEIG NORDSTRÖM: UNA MIRADA HACIA EL PASADO DE LA ESCUERA

Raúl Berenguer González ..

\section{ARQUEOLOGÍA Y MÉTODO}

EL ESTUDIO DE LOS MATERIALES CONSTRUCTIVOS DE TIERRA DEL CABEZO DEL POLOVAR (VILLENA, ALICANTE): APORTACIÓN A LAS FORMAS CONSTRUCTIVAS DE DOS PEQUEÑAS EDIFICACIONES CAMPESINAS DE LA EDAD DEL BRONCE EN EL LEVANTE PENINSULAR

María Pastor Quiles

VIVIENDAS POSTALAYÓTICAS: UNA APROXIMACIÓN A LOS ESPACIOS DOMÉSTICOS EN EL ARCHIPIÉLAGO BALEAR (550-123 ANE)

Octavio Torres Gomáriz

LAS FLOTAS DE GUARNICIÓN ROMANA EN LAS COSTAS DE HISPANIA A PARTIR DE LAS FUENTES EPIGRÁFICAS

Sergio Lledó Ramírez

UNA APROXIMACIÓN A LA RECONSTRUCCIÓN DEL PAISAJE HISTÓRICO: EL PROYECTO L'ALMISSERÀ Diana López Arroyo

NUEVAS PERSPECTIVAS PARA EL ESTUDIO ARQUEOLÓGICO DEL POBLAMIENTO RURAL MEDIEVAL EN ASPE (ALICANTE): HUERTAS Y ALQUERÍAS JUNTO AL RÍO TARAFA

Felipe Mejías López

ARQUEOLOGÍA DE LAS GUERRAS CARLISTAS

Iván Roldán Vergarachea

LA CERÁMICA DE USO ARQUITECTÓNICO EN NOVELDA: LA AZULEJERÍA DE FINALES DEL SIGLO XIX Y PRINCIPIOS DEL XX

Natalia Sala Pérez

PRÁCTICA Y USOS DE LA FOTOGRAMETRÍA DIGITAL EN ARQUEOLOGÍA

Ana $M^{a}$ Charquero Ballester.

\section{GESTIÓN Y PUESTA EN VALOR DEL PATRIMONIO}

ARQUEÓLOGOS CON DISCAPACIDAD. ARQUEOLOGÍA INCLUSIVA

Ana Samaniego Espinosa

"LES COVES DELS PESCADORS DE EL CAMPELLO": PROPUESTA DE RECUPERACIÓN, PUESTA EN VALOR Y USO PÚBLICO DE UN PATRIMONIO OLVIDADO

Ana Isabel Castro Carbonell .

LA COLONIA DE SANTA EULALIA. ESTUDIO Y PROPUESTA DE RECUPERACIÓN

Héctor de Arriba González

PROYECTO DE PUESTA EN VALOR DE LOS RESTOS DE LA GUERRA CIVIL EN LA CIUDAD DE ALICANTE

Leticia Victoria González Chouciño

ANTEPROYECTO MUSEOGRÁFICO DEL MUSEO DE HISTORIA DE SAX

Alberto Ochoa García

EL CONGRESO DE MÁSTER: UNA PROPUESTA DIDÁCTICA DEL MÁSTER DE ARQUEOLOGÍA DE LA UNIVERSIDAD DE ALICANTE

Ignasi Grau Mira, Sonia Gutiérrez Lloret, Carolina Doménech Belda, Julia Sarabia Bautista 



\title{
ANTEPROYECTO MUSEOGRÁFICO DEL MUSEO DE HISTORIA DE SAX
}

\author{
Alberto Ochoa García
}

\section{RESUMEN}

El siguiente trabajo supone un resumen del proyecto efectuado en el curso 2009-2010, tutelado por el profesor Francisco Javier Jover Maestre. Este proyecto se desarrolló en colaboración con el Ilmo. Ayuntamiento de Sax con tal de efectuar un proyecto real. Se estudió el edificio que se consideró propicio para localizar el centro museístico, y se estudiaron todas las colecciones municipales, tanto la colección documental, fotográfica, arqueológica y etnográfica, además de incluir piezas relevantes de colecciones privadas para completar el discurso expositivo. Este trabajo se ha desarrollado en varias direcciones. Por un lado se ha convertido en un proyecto museográfico y museológico básico, presentado en dos postgrados. Por otro lado, se ha completado con estudios sobre aspectos como la interactividad, la accesibilidad, la función de desarrollo social y cultural o la concepción del proyecto como centro de gestión integral del patrimonio para presentarlo a distintos congresos. Por último, ya sabiendo el proyecto que el municipio de Sax necesitaba, se ha convertido en un museo virtual, con tal de crear una opinión sobre el proyecto y saber el proyecto que les gustaría tener a los sajeños, además de crear una herramienta de difusión de los estudios sobre el patrimonio sajeño que se han ido desarrollando a raíz de este trabajo.

Palabras claves: Sax, museografía, museología, museo virtual, patrimonio

\begin{abstract}
The following paper is a summary of the project carried out in the 2009-2010 course, mentored by Professor Francisco Javier Jover Maestre. This project was developed in collaboration with the Hon. Sax Town Hall so to make a real project. the building that was deemed suitable to locate the museum center was studied, and all municipal collections were studied, both the documentary, photographic, archaeological and ethnographic, collection and includes pieces from private collections relevant to complete the exhibition discourse. This work has been developed in several directions. On the one hand it has become a staple museum and museum project, presented two postgraduates. On the other hand, it has completed studies on aspects such as interactivity, accessibility, the role of social and cultural development or project design as a center of comprehensive wealth management for submission to various conferences. Finally, already knowing the project that the municipality of Sax needed, it has become a virtual museum, just to create an opinion on the project and know the project they would like to sajeños and create a tool for dissemination studies on the sajeño heritage that have developed as a result of this work.
\end{abstract}

Key words: Sax, museology, museology, virtual museum, heritage 


\section{UN ANTEPROYECTO}

La primera intención era la realización de un proyecto formal sobre el que ya levantar el museo, pero la indisponibilidad de un estudio previo, unido a la falta de unos fondos importantes sobre los que trabajar y la imposibilidad de poseer una planimetría sobre la división interna del edificio donde se pretende levantar el museo, hacían necesaria la realización de un anteproyecto.

Para la realización de este proyecto se tuvo que tener en cuenta la opinión del Ayuntamiento de Sax, ya que se concebía como un museo municipal. El deseo de la corporación era levantar un museo referente, principalmente, al siglo XIX, como la etapa más destacable de la historia de la Villa.

El proyecto se concebía tanto como un museo tradicional, por la necesidad de gestionar correctamentelos bienes muebles de la colección municipal (Alonso, 1999). Además de estos objetivos generales, el museo también seguiría otros específicos, con tal de convertirlo en un producto patrimonial de calidad (Santacana et al., 2005). Así

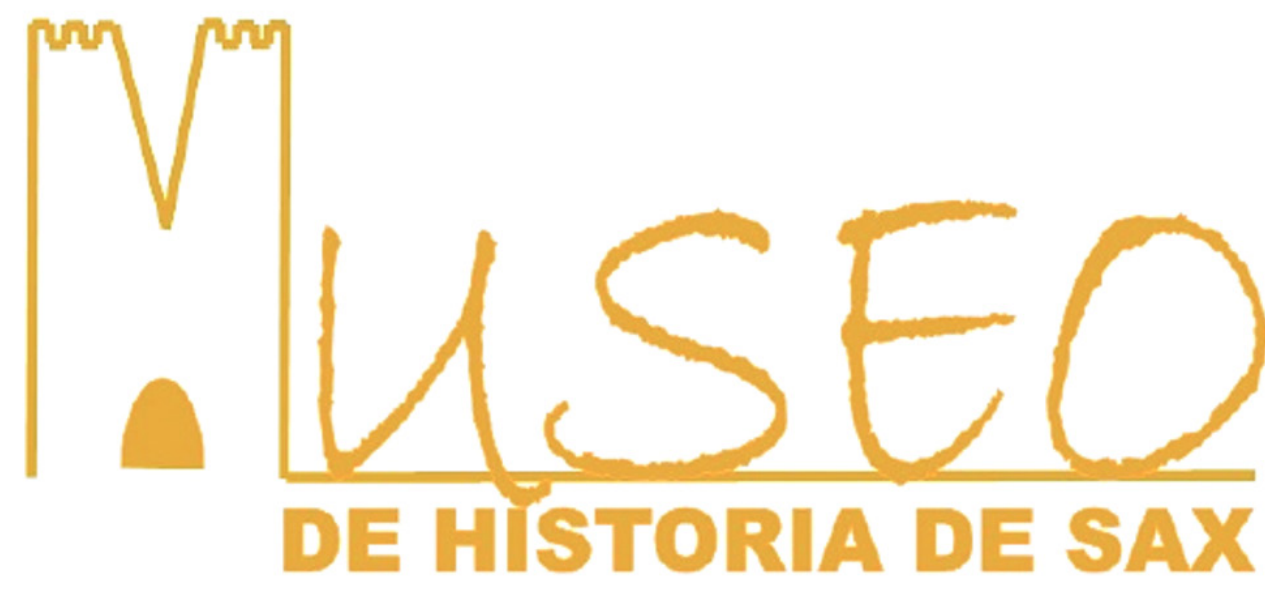

Fig. 1. Logotipo del Museo de Historia de Sax. Elaboración propia desarrollaríamos unos objetivos científicos unidos a la difusión de los bienes que representan la historia de Sax, mostrar los elementos más relevantes de la misma, crear un museo pedagógico e interactivo o la posibilidad de instruir a los visitantes. Además se contemplarían una serie de objetivos socioculturales como la contribución al conocimiento de la población, el carácter educativo del centro, la sensibilización con el patrimonio, incentivar la donación de colecciones y desarrollar servicios indirectos, contribuyendo al desarrollo social, cultural y económico de la población.

Del mismo modo, en ese momento se tuvieron en cuenta una serie de leyes que entonces eran las que estaban en funcionamiento. En el caso del Museo de Historia de Sax este se debería de ajustar a la Ley 4/1998 del 11 de junio, de la Generalitat Valenciana, del Patrimonio Cultural Valenciano y a la Orden de 6 de Febrero de 1991, de la Conselleria de Cultura, Educación y Ciencia, además de al Código de Deontología del ICOM.

Estos tres cuerpos legislativos establecen los criterios de reconocimiento de los museos, las características de las instalaciones, las funciones que deben desarrollar o los criterios de conservación que se deben desarrollar en relación a las colecciones tanto expuestas como almacenadas.

\section{ACTUALIDAD MUSEÍSTICA DE LA PROVINCIA DE ALICANTE}

Este fue uno de los aspectos que desarrollamos también posteriormente, en otros trabajos (Ochoa, 2014) pero sí que hay algunos aspectos destacables que es preciso apuntar, ya que sirven de modelo para desarrollar este museo.

Son varias las clasificaciones de museos que se pueden encontrar, pero el ICOM los clasifica en 
Museos de Arte, Museos de Historia Natural, de Etnografía y Folklore, Museos Históricos, de las Ciencias y de las Técnicas, de Ciencias Sociales y Servicios Sociales, Museos de Comercio y de las Comunicaciones y Museos de Agricultura y de productos del suelo. En nuestro caso, los tipos de museos que afectan a este proyecto son los históricos. En este grupo el ICOM diferencia 8 subtipos, como son los biográficos (referidos a grupo de individuos), las colecciones de objetos y recuerdos de una época determinada, los conmemorativos (de algún acontecimiento), los biográficos de un solo personaje, los de historia de una ciudad, los arqueológicos, los de guerra y del ejército y los de la marina.

De los subtipos de museos referentes a la historia de los que apunta el ICOM, en la provincia de Alicante son predominantes, sobre todo, los museos arqueológicos (Azuar, 2000). En el entorno de Sax, en el alto y medio Vinalopó, ya existen museos de reconocida importancia, como los de Elda, Petrer o Villena. Dentro de los museos históricos que reconoce el ICOM son también destacables en el entorno de Sax (Soler y Castells, 2000) el del botijo de Villena, el del escultor Antonio Navarro Santafé, en su vertiente biográfica, la colección museográfica Casa "el Cisco" de Aspe, el Museo del Calzado de Elda, el Museo de Artes y Oficios de Monóvar, la Casa Museo Azorín, de la misma localidad, o la Casa Museo Modernista de Novelda.

Estos son ejemplos destacables dentro de la oferta museística de la provincia de Alicante, pero también se encuentran en la geografía española otros museos que también serán referentes para este anteproyecto del Museo de Historia de Sax, como el museo de la Universidad de Murcia (García, 2005), en Cataluña la exposición de instrumentos musicales, sobre todo extremo orientales, en los distintos museos (Serra, 2009) o, sobre todo Andalucía, donde destaca la exposición de Medinat al-Zahra, las actividades de barrilería del museo provincial de la Uva de Barco (Buena, 2008) o la exposición "Torredonjimeno. Tesoro, monarquía y liturgia. Exposición temporal en el Museo Arqueológico y Etnológico de Córdoba" (Carpio, 2004).

\section{EL EDIFICIO DEL MUSEO DE HISTORIA DE SAX}

En las conversaciones mantenidas con el Ayuntamiento de Sax se nos propuso el desarrollo del proyecto en un edificio contiguo al del Centro de Estudios y Archivo Histórico Municipal "Alberto Sols". Este edificio era privado, por lo que tuvimos el inconveniente de no poder acceder al mismo para realizar el estudio arquitectónico.

Esta vivienda ocupa $445 \mathrm{~m}^{2}$ de suelo, estando dividida en dos plantas de unos cien metros cuadrados, sótano, patio trasero y garaje. El edificio se demolería para igualarlo al edificio contiguo, tanto estética como estructuralmente (Hernández, 1994).

Como hemos comentado, el CEAHM "Alberto Sols" y el museo se encontrarían conectados, de tal forma que se encontrarían, por lo menos, dos uniones entre los dos edificios. Los espacios públicos contemplan desde la recepción a las distintas salas, pero también el patio, que formará parte del discurso expositivo. A través de este espacio se realizará la segunda conexión del museo con el CEAHM, comunicándose con el patio del segundo.

Dentro de un museo también deben de existir otros espacios públicos, como son la sala de exposiciones temporales, la sala de conferencias y la de investigación. Estos espacios no constarán en el edificio de este museo, puesto que la conexión entre el CEAHM y el museo se efectúa, principalmente, para el aprovechamiento de esos espacios ya existentes, como la sala de conferencias, los almacenes, las salas de investigadores o la sala de exposiciones. Del mismo modo, se aprovecharían los espacios del CEAHM para establecer los espacios privados del museo, como las oficinas de gestión. 
A pesar de esto, el museo también necesitaría espacios de servicios que ya se deberían de plantear fuera de los dos edificios, sobre todo temas de mantenimiento, almacén de piezas grandes y demás.

\section{LOS FONDOS PARA EL MUSEO}

Los bienes muebles que formarían parte de este museo proceden de colecciones municipales y privadas. Por un lado, las colecciones municipales se dividen en la colección arqueológica, la etnográfica y la documental. La colección arqueológica posee fondos procedentes de las excavaciones efectuadas en la peña del castillo y materiales procedentes de las prospecciones realizadas en el término municipal, integrando piezas desde la Edad de Bronce hasta casi la actualidad. La colección etnográfica está nutrida, principalmente, por los préstamos efectuados por Joaquín Estevan y Vicente Vázquez Linares. Esta colección contiene elementos referentes a los tratamientos del vino, elementos de esparto, cerámica o herramientas de los trabajos del campo. Por último, de la colección documental, situada en el Archivo Histórico Municipal, dentro del CEAHM, destacando tanto documentos como fotografías y distintos legados, como el de Alberto Sols, Miguel Villar, y los fotógrafos Uñack y Payá.

Dentro del estudio sobre las piezas que podrían conformar parte del Museo de Historia de Sax también se han estudiado piezas de colecciones privadas que podrían, en el momento, completar el discurso expositivo, como las de Julia Valdés, Pedro Estevan Alpañés, el "Maestro Requinto", Antonio Sarrió Martínez, Pedro Picó, la de la Bodega Cooperativa del Campo de San Blas, o la de la familia de "Los Flautas". Todas estas hablarían de distintos aspectos del siglo XIX y principios del XX, como la vida cotidiana de la alta burguesía, la música y la ebanistería o el trabajo en el campo.

\section{EL DISCURSO EXPOSITIVO}

El objetivo principal de un museo es establecer un diálogo entre la exposición y el visitante, lo que, en nuestro caso, es uno de los objetivos principales. Así pues, nuestro discurso será plenamente didáctico, donde la interactividad (Requejo, Mascarell, Paré, 2009) sensorial va a ser el factor explicativo predominante en las salas.

\subsection{La primera planta}

En esta primera planta se encontraría la recepción, que es muy importante, debido a que aquí el visitante tiene su primer contacto con el museo. El discurso para este espacio incluiría un audiovisual con la historia de Sax, además de un interactivo que se titularía "Tú también puedes formar parte de la historia de Sax", donde todos los visitantes podrían poner sus fotos que estén efectuadas en algún lugar de Sax.

Desde la recepción se daría acceso a la primera sala. Esta sala se plantearía como un centro de interpretación de la historia de Sax. Todas las secciones irán acompañadas por una línea temporal donde figurarán los acontecimientos de la historia de España y de la Comunidad Valenciana donde ha participado Sax.

En el centro de la sala se encontrará un elemento referente a toda la sala. La idea principal era la instalación de una maqueta que muestre toda la evolución urbana de la población. Esta maqueta estaría acompañada de dos paneles que harían referencia a la Iglesia de Nuestra Señora de la Asunción y el castillo, debido a que, como tienen una evolución muy amplia sería complicado que los visitantes atendieran a esa evolución si se divide en distintas secciones.

Dentro del proyecto presentado en el máster se desarrolló todo el discurso textual, pero aquí no vamos a desarrollarlo todo. Si que podemos decir que en esta primera planta se comenzaría hablando del poblamiento del territorio desde la prehistoria, con una primera referencia al mar Cretácico que 


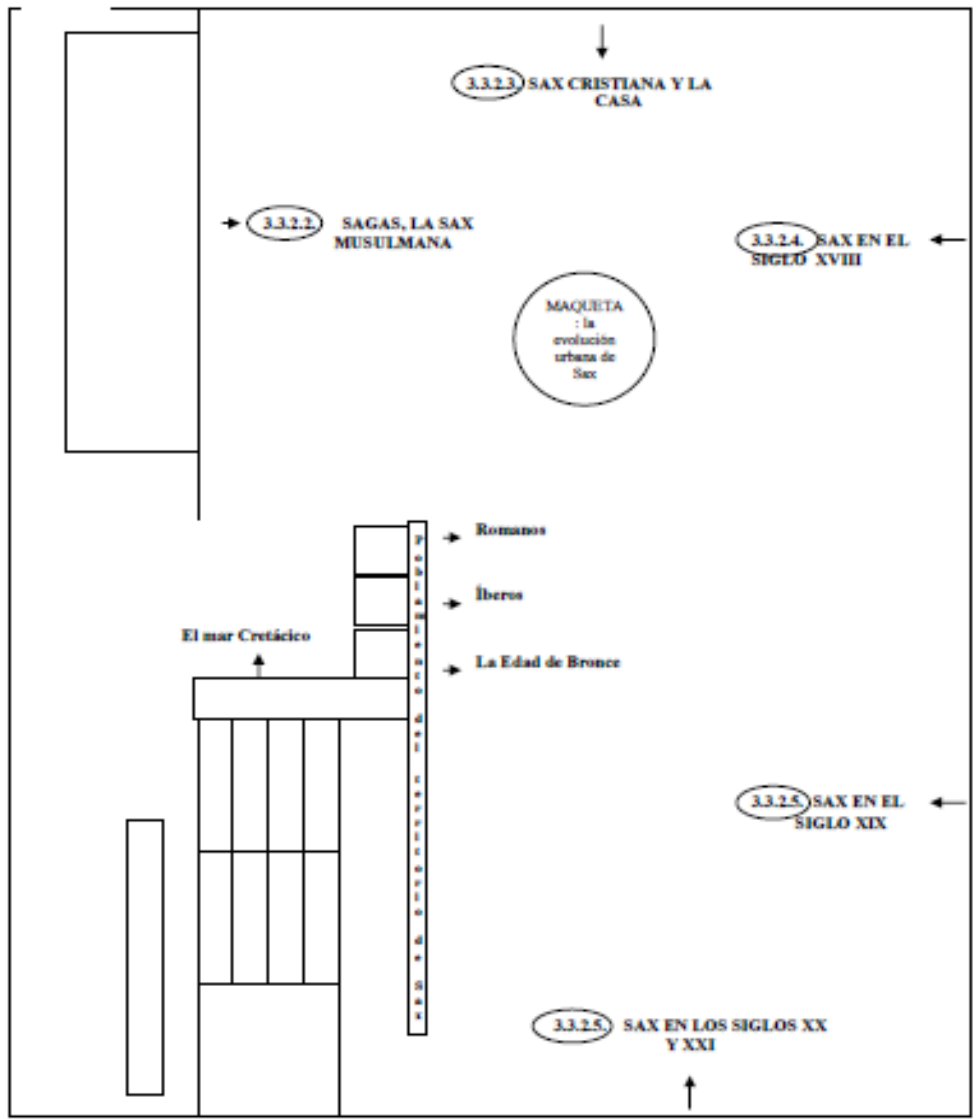

Fig. 2. Croquis de la primera planta del museo lo cubría todo en aquel entonces. Allí se hablará de la Edad de Bronce, con las piezas encontradas en el Peñón del Rey, el Puntal, el Peñón de la Moneda o la Peña del Castillo (Hernández, 2005). La sección central de esta zona introductoria representará la reproducción de la escultura del toro ibérico del Chorrillo (Poveda, 2009), mientras que el tercer apartado de esta sección introductoria se referirá a la ocupación romana de la zona, exponiéndose cerámica sigilata, de barniz negro, monedas, tegulae $\mathrm{y}$ fragmentos de sarcófago, todo ello tanto de la colonia de Santa Eulalia como del paraje de la Torre (Peidró, 2009).

Ya dentro de la sala se desarrollaría una primera sección referente al período musulmán de Sax, con los datos cronológicos pertinentes (Tendero, 2005) y las piezas más interesantes, donde sería importante exponer la pipa almohade depositada en el Museo Arqueológico de Elda (Pérez, 2005). En la parte central de la sección se incluiría la referencia que aparece en la obra de al-Himyari, escrita en el siglo XII, en la que dice: "S(a)g(a)s: Ciudad de al-Andalus, cerca de Petrer. Es un pueblo importante y próspero. Está a poca distancia de Játiva".

El montaje expositivo continua con la baja Edad Media en Sax y la conquista cristiana de estas tierras. El discurso expositivo de esta sección podría incluir desde los frescos del castillo de Alcañiz, que narran la conquista de estas tierras, al cuadro o los dibujos de José Martínez Antolín referentes a la muerte de Artal de Alagón en Sax y a la visita de los reyes católicos. Además, en la parte baja figurará un atril donde se expondrán documentos que se encuentran en el Archivo Histórico Municipal, referentes a la relación de Sax tanto con el Marquesado de Villena como con la corona de Aragón y la casa de Austria.

A continuación se encontraría la sección referente a la época moderna, con especial atención al siglo XVIII. En este caso, se encuentran tres temas principales referentes a Sax: la evolución urbana; la visión de Sax por parte de los extranjeros que visitan Sax; y la participación de Sax en la Guerra de Sucesión, terminando la sección con la concesión a la villa del nombre de "Muy Noble y Muy Leal Villa de Sax", acompañando todo esto a un atril en la parte baja que presentaría los documentos referentes a esta guerra, muy importantes e interesantes en Sax.

También se haría aquí una pequeña introducción del siglo XIX, ya que en las siguientes salas se desarrollaría el discurso. Sí que se encontrará en esta sala, como elemento central de esta época el plano efectuado por Antonio Estevan Barceló en 1917, donde se muestran los principales edificios que se construirían a finales del siglo XIX. Esta sala finalizaría con una referencia al siglo XX y lo que llevemos de siglo XXI cuando se inaugure el museo. En esta sección se hablará, principalmente, 


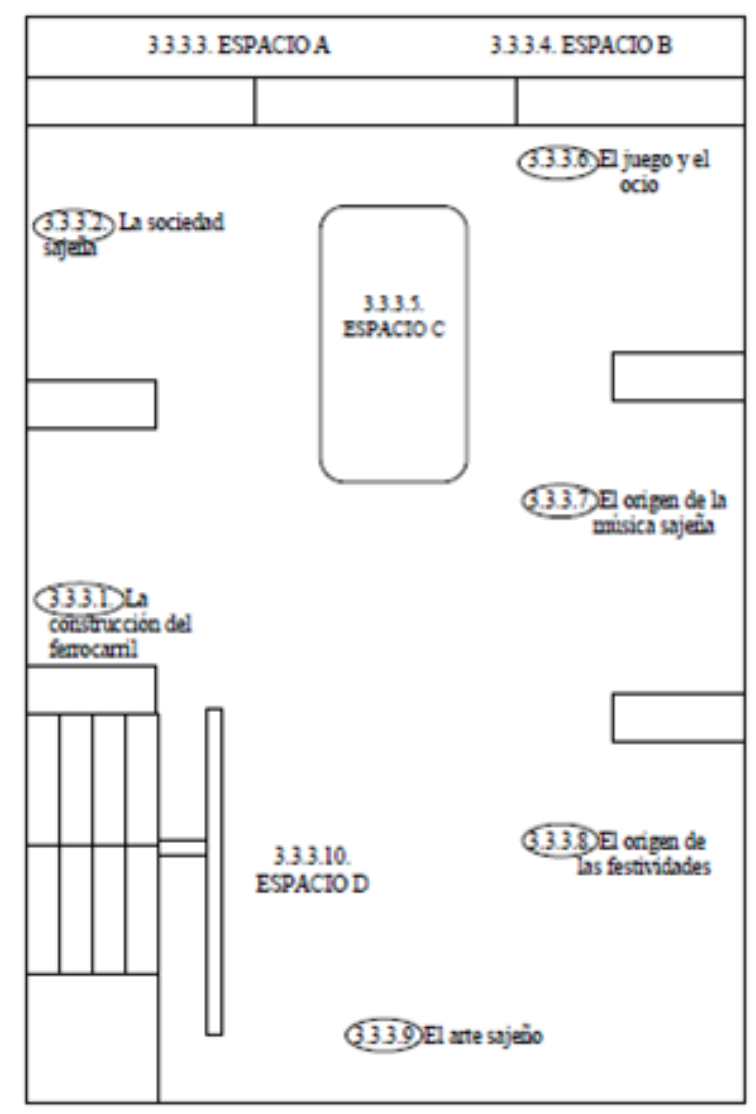

Fig. 3. Croquis de la segunda planta del de los motores económicos actuales de Sax, como son los zapatos y las persianas, acompañando la información con piezas de la colección etnográfica municipal. Todo ello representado en la evolución urbana de la población.

\subsection{La segunda planta}

En esta sala se pretende que el visitante sienta que se encuentra dentro de una vivienda, que puede "andar" entre los habitantes de esta supuesta vivienda y que puede escuchar, oler, tocar y ver lo mismo que los protagonistas del siglo XIX.

Hemos pensado que se encuentran muchas fotografía donde se observa el vestuario de las damas, caballeros y niños de esta época y que se podrían aprovechar para ponerlos en la sala, pero no como simple decoración, sino que el rostro de estas personas se eliminaría, salvo elementos como bigotes o velos, para instalar en ese hueco un espejo y que los visitantes se vean reflejados en ellos y que se sientan como que llevan puestos esos trajes y vestidos. La ambientación de la sala también incluirá una ambientación sonora, tanto como "decoración" como musealización del sonido, puesto que se ha propuesto museo.

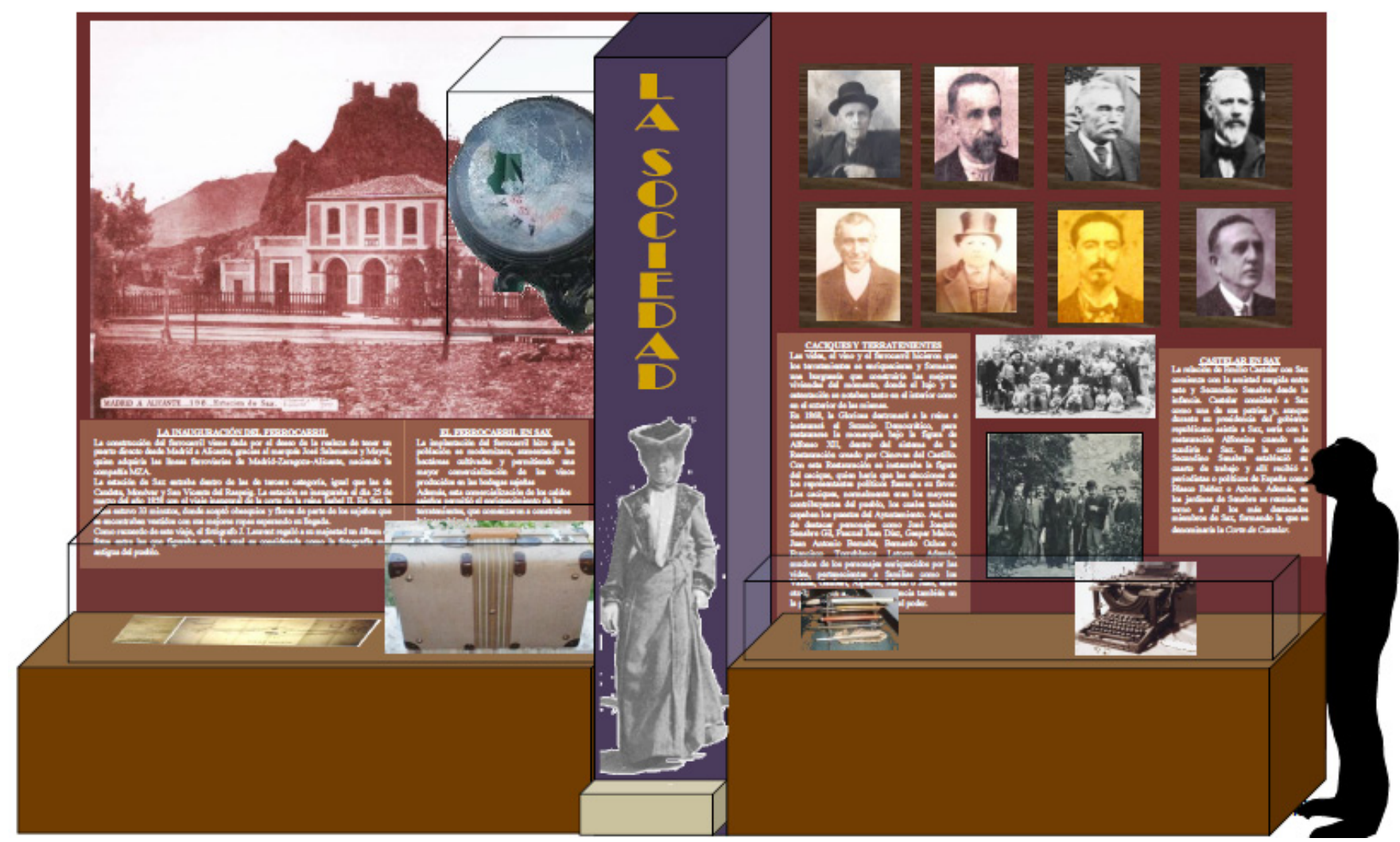

Fig. 4. Montaje expositivo referente a la llegada del ferrocarril y a la sociedad de la segunda mitad del siglo XIX, con la división entre secciones con las figuras de personajes del siglo XIX. Elaboración propia 
recuperar música de esos momentos que bien podría ser de procedencia extra-sajeña, atendiendo al repertorio lírico o zarzuelístico del momento, como las obras de Ruperto Chapí, o sajeña, ya que en el siglo XIX, compositores como Pedro Estevan Alpañés, el "Maestro Requinto", compusieron gran cantidad de música, entre obras religiosas, polkas o pasodobles o música de salón que se podrían recuperar y grabar, como otras de las funciones del museo.

El discurso expositivo de esta sala comienza con el ferrocarril. En esta sección destacan tres elementos principales, uno documental, el proyecto de la construcción de la estación, del Archivo Histórico Ferroviario, FFE, la maleta de la colección de Pedro Picó y el reloj que se encuentra en la estación, que por conservación podría trasladarse al museo (Linares, 2008).

A continuación se hablaría de la sociedad, con dos temas principales, como son el caciquismo y las visitas de Emilio Castelar a Sax. La escenografía de esta sección presentará los retratos de los personajes más influyentes en la población, tanto fueran caciques, miembros del poder local o terratenientes, además de un apartado referente a las visitas de Castelar, con fotografías con un grupo de ilustres sajeños y otra con Secundino Senabre, Azorín y Blasco Ibañez, entre otros personajes destacables. Como objetos representativos de ese caciquismo hemos pensado que podían aparecer elementos como una máquina de escribir, los elementos de escritorio utilizados entonces, o monedas de ese momento (Hellín, 2008).

La siguiente sección se referirá al ocio y al juego, con referencia a los dos edificios más importantes en este tema, como el teatro y el casino. Seguramente, una buena pieza sería la reconstrucción, por medio de una maqueta, del casino, ya que aún perdura en la memoria de algunos vecinos. Esta sección se une a la siguiente que hablará del origen de la música sajeña y la gran evolución que tuvo en este período, con piezas del Maestro Gusi y del maestro Requinto y de las bandas que existían entonces, la conocidas como "La Primitiva" y "La Moderna" (Martínez, 2005, Vázquez, 2005, Ochoa, 2009). Igualmente unida a esta sección se encontrará la referente al origen de las festividades de Sax, tanto las de San Blas como el resto (Gil, 2008).

La última sección de esta sala del Museo de Historia de Sax estaría dedicada al arte desarrollado en el siglo XIX. En esta sección se expondrían tanto elementos originales como reproducciones tanto de obras de ebanistería como de pinturas. Las obras pictóricas serán, sobre todo, las de Baldomero Viñas y Bernardo Herrero y los retratos de Isabel Guillén y Pedro Náger y las de ebanistería, sobre todo, serán las de Pedro Estevan Alpañés (Llopis, 2008).

\subsubsection{Espacios interactivos}

Dentro de la configuración escenográfica de la sala pensamos incluir una serie de espacios interactivos y escenográficos referentes a la vida del siglo XIX. El primero de ellos sería el salón. En él se podrían encontrar dispuestos los bienes muebles que se conservan en la colección municipal, pertenecientes a la casa de Alberto Sols. El otro espacio escenográfico sería el de la alcoba, que también estaría compuesto por las piezas de la familia de Alberto Sols. Delante de estos dos espacios se encontraría una vitrina con elementos representativos del mundo masculino, el mundo femenino, y el servicio de mesa.

El tercer espacio sería una mesa de salón que se emplazaría en el centro de la sala. Los platos, cubiertos y elementos de servicio se encontrarán en la mesa, bien sujetos para evitar cualquier robo o percance, acompañados de la decoración pertinente para una mesa como la del museo. Todo acompañará a un interactivo con pulsadores para activar ventiladores con olores de la época. 


\subsection{La tercera planta}

La tercera y última sala del museo sigue refiriéndose al siglo XIX en Sax, pero trasladando el discurso al campo y a la parte de la sociedad que trabajaba en las distintas plantaciones. Esta sala se encontrará en la tercera planta del museo, la cual se debe construir, por lo que esta, para responder a la tipología de las viviendas del siglo XIX, debería de estar cubierta a dos aguas, pudiéndose observar las vigas. En esta sala hemos pensado desarrollar cuatro secciones solamente, donde se hablará del campo durante ese siglo, la división agrícola y los caminos, la Colonia Agrícola de Santa Eulalia y el proceso de producción del vino sajeño.

La primera sección de esta sala se dedicaría al campo sajeño en el siglo XIX. Esta sección mostrará el trabajo en el campo en general, pero especificando, sobre todo, la actividad cerealícola, para, así, exponer la mayoría de los elementos que componen la colección etnográfica municipal, además de los de la colección de Antonio Sarrió Martínez (Sarrió, 2006).

La segunda sección se referirá a la colonia de Santa Eulalia, teniendo como pieza central una maqueta de todo el complejo industrial. La sección se completaría con un panel con la explicación de todos los edificios del complejo, además de la documentación relativa

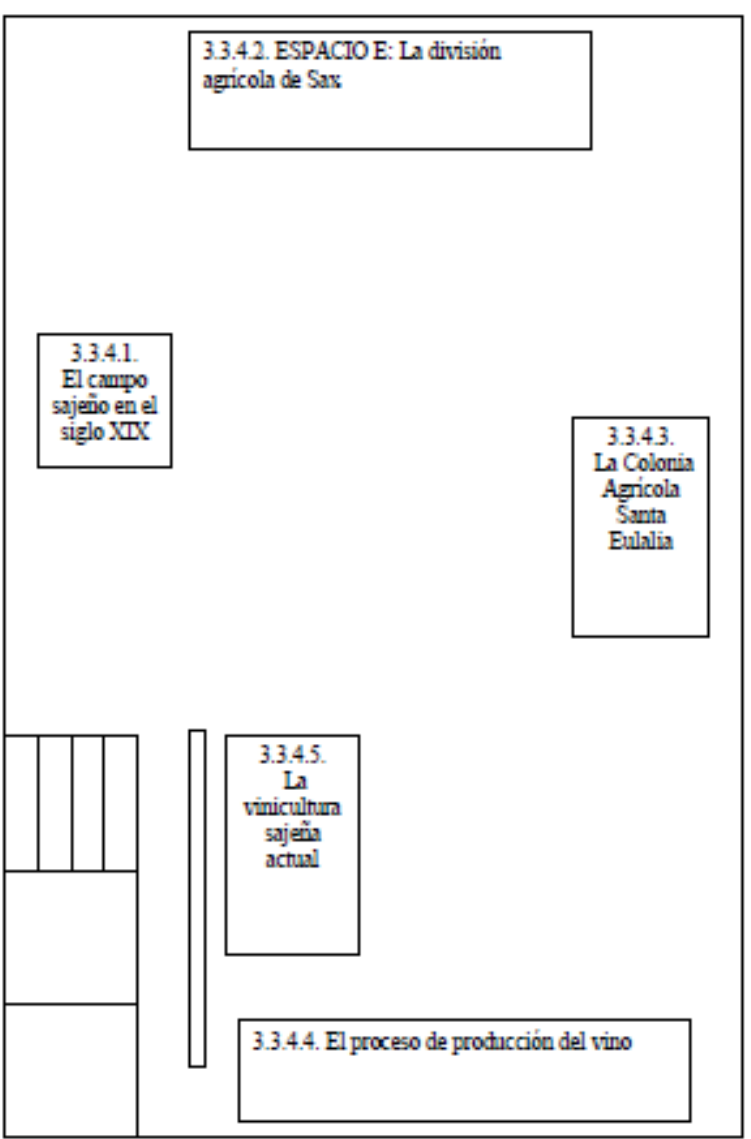

Fig. 5. Croquis de la tercera planta del museo. a la fundación. Destacar, sobre todo, la colección de postales de la época que se expondrán, además de la iniciativa de recuperar elementos en peligro de extinción que se encuentran en la colonia (Jaén, Lillo, Sánchez, 2005).

La tercera sección se referirá a la producción del vino. La sección se articularía en torno a la muestra de instrumental para la vendimia, del cual posee la colección etnográfica municipal, una báscula y una prensa, que pertenecen a la Bodega Cooperativa, aunque sea de los años 20 del siglo XX, algunos de los instrumentales de análisis del vino que se encuentran en la colección etnográfica, que pertenecfieron al agrónomo Pascual Carrión, y, por lo menos, uno de los barriles que posee la Bodega Cooperativa. Dentro de esta exposición podrían formar parte botellas de vino, si se encontraran, del siglo XIX, o algunos de los galardones conseguidos por la bodega que tenían los familiares de Julia Valdés, u otras familias (Giménez, 2008).

Dentro de esta sección se desarrollaría lo que hemos denominado como el "Espacio F", que consistiría en una serie de columnas donde se expondrían las botellas de la producción vinícola actual, además de información y un interactivo también con olores.

\subsection{El huerto-jardín del siglo XIX}

Uno de los atractivos de este proyecto hubiera sido la reconstrucción de un huerto-jardín, ya que esta era una zona importante en la configuración de la vivienda, para el esparcimiento de la familia y 


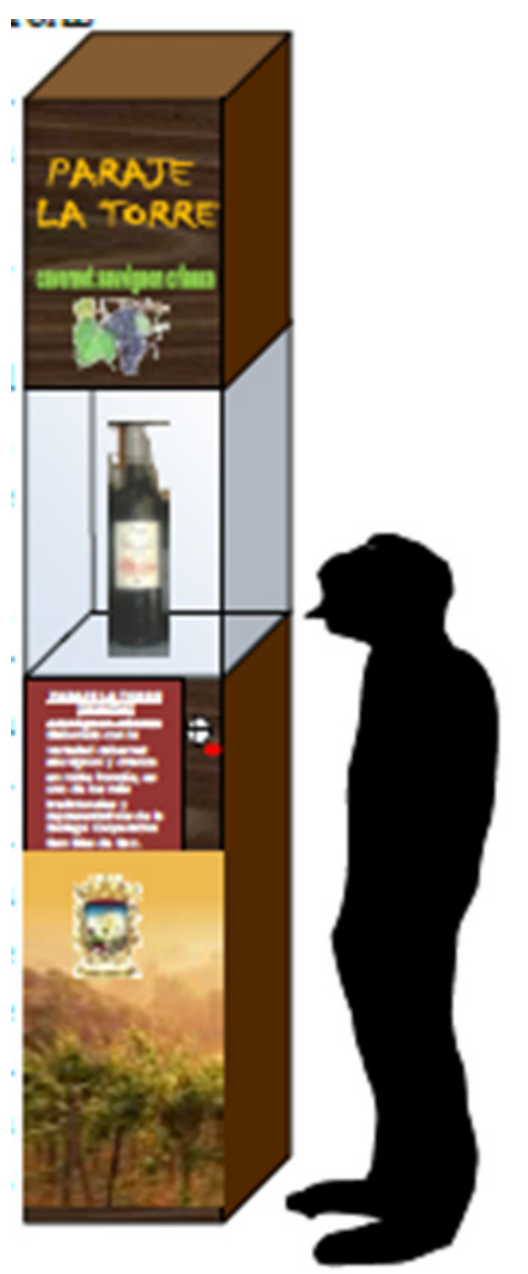

Fig. 6. Elemento interactivo referente al vino que se produce en Sax, con una zona de exposición, información y pulsador para olores. Elaboración propia. los visitantes. La idea era reconstruirlo para configurar una cuarta sala del museo, pero al aire libre. En él se plantarían algunas de las especies vegetales presentes en la segunda mitad del siglo XIX, como pueden ser las palmeras datileras o las parras, aunque se podrían decorar los espacios libres con algunas especies que den flor, como la lavanda o el romero, que eran utilizados entonces.

El elemento central sería una fuente que se podría recuperar de la vivienda número 36 o se reproduciría, ya que este es uno de los elementos que marcaba la riqueza a la que llegaron los habitantes de esta casa, que ya aparecen en una fotografía de 1916 en torno a la fuente, para luego configurar una pequeña zona de huerto con las distintas variedades de vid, además de las zonas de sombra y paseo.

\section{LAS ACTIVIDADES DE DIFUSIÓN}

Un museo debe de procurar que sus funciones no queden encerradas en las paredes del mismo, sino que su actividad debe superar estas barreras y llegar a toda la población, tanto de la localidad donde se sitúe como de fuera. En este momento consideramos la difusión como una de las principales funciones que desarrollaría el museo. De esta forma, agrupamos las actividades en actividades científicas y pedagógicas.

Dentro de las actividades científicas se incluirían todos los resultados de las investigaciones que se realizan dentro del centro, que se expondrían bien en publicaciones, tanto físicas como online, exposiciones temporales o ciclos de conferencias.

En cuanto al segundo grupo de actividades, las pedagógicas, debemos tener claro que el principal activo de un museo son los estudiantes, de distintos niveles. En torno a ellos, pero no de forma exclusiva, sino abiertos a todos los tipos de visitantes, se podrías desarrollar distintos tipos de talleres, dentro de los que podrían incluirse las degustaciones, con la colaboración de la Bodega Cooperativa. Del mismo modo, dentro de este grupo de actividades se incluirían las visitas guiadas, además de las visitas teatralizadas enfocando todo ello a la atracción del público.

\section{PROYECTO BÁSICO MUSEOLÓGICO Y MUSEOGRÁFICO}

Una vez presentado en el congreso del máster este trabajo, se presentó también al Ilmo. Ayuntamiento con la intención de llevarlo a la realidad. En el transcurso de poco tiempo hubo un cambio de legislatura política que hizo que, entre otras cosas, desecharan este proyecto, por lo que utilizando este trabajo como base de estudio efectuamos en proyecto básico museológico y museográfico.

Esta continuación lógica del trabajo se desarrolló como trabajos finales del Curso de Especialista Universitario en Gestión del Patrimonio, de esta universidad también, y del Postgrado en Desarrollo y Aplicaciones en Museografía Interactiva de la Universidad de Barcelona.

Con todos estos cambios, el proyecto evolucionó y cambió. El nombre ahora sería el de Museo de la Villa de Sax, mientras que la localización también cambiaba para pasar a estudiar un edificio 
de propiedad municipal al que pudimos acceder y estudiarlo detenidamente. Este proyecto era aún más grande que el anteproyecto, puesto que ya se debían de asentar las bases sobre las que levantar el futuro museo. Es por ello que se optó por crear un pequeño equipo de arquitectos, diseñadores gráficos, diseñadores de estructuras, maquetas, fotógrafos y demás. En el curso de especialista se desarrolló el trabajo museológico, mientras que en el postgrado se desarrolló la parte museográfica.

El proyecto básico museológico del Museo de la Villa de Sax fue dirigido por Gabino Ponce. Este proyecto ya se enmarcó teóricamente dentro de la museología crítica de la nueva museología junto al cambio de enfoque que lleva a redefinir al museo como un centro de gestión integral del patrimonio, donde lo importante son las piezas, pero también los visitantes, teniendo el museo la función de interactuar entre visitantes, piezas e institución, y teniendo como elementos característicos el desarrollo de cinco funciones internas, las típicas de adquisición, conservación, exposición, difusión e investigación, además de seis nuevas que hacen que el museo salga del edificio, convirtiéndose en un centro de recepción, en un centro de visitantes, en una oficina de turismo, en un centro cultural, en el guardián del patrimonio o en el reactivador del patrimonio local, todo influyendo en el desarrollo local, sobre todo social y cultural, además de crear riqueza endógena.

En este caso el estudio arquitectónico tuvo mucho peso, siendo desarrollada la planimetría por la arquitecta Juana Arranz. Aquí se efectuó un diseño de salas y recorridos con un sentido muy premeditado y teniendo como base la obra de Chinchilla (Chinchilla, 2005) "Criterios para la elaboración de un plan museológico". Con esta base se estudió la historia del edificio, la arquitectura y la distribución espacial, la reconstrucción del edificio, la accesibilidad, seguridad y la configuración espacial con las áreas públicas sin bienes culturales muebles, las áreas públicas con bienes culturales, las áreas internas con bienes y las internas sin bienes.

Así, con el análisis de todas estas áreas que establecían los “Criterios" se desarrollaría un museo que modificaría estructuralmente el edificio existente para darle un discurso circular y proporcionarle unas zonas de gestión, aunque para almacén y desarrollo de algunas funciones debería seguir dependiendo de servicios y equipamientos externos. El edificio se configuraba en una planta de recepción, con una sala polivalente de audiovisual y exposiciones temporales y el acceso al almacén de sótano. La escalera principal comunicaría con las dos plantas de exposición permanente, mientras que la escalera secundaria dirigiría al área de servicio, con unos despachos, una pequeña biblioteca y archivo y un laboratorio y almacén de recepción.

En este sentido también se profundizó más en el desarrollo del programa de difusión y comunicación, proyectando ya hasta la guía breve del museo. Esta guía, por las características que se le estaban adjudicando al proyecto, debía convertirse también en la guía del patrimonio de la localidad. De tal forma que dentro de ella se hablaría de la historia de la población, los bienes patrimoniales más destacados, el centro histórico, el castillo, la colonia de Santa Eulalia, los bienes etnográficos inmuebles, el patrimonio inmaterial. Por supuesto, también se hablará del museo y sus secciones y se incorporarán unos planos de recorrido, al igual que otros de la localización de los bienes culturales en la población. El modelo que se eligió para el desarrollo de esta guía fue el de las guías breves de los museos nacionales, siendo esta una publicación de pequeño tamaño, que cabría en el bolsillo, con 100 páginas. Fácil de leer y cómoda de llevar en el paseo por el museo y por Sax.

El proyecto básico museográfico del Museo de la Villa de Sax fue tutorizado por Julia Castell del IL3 de la Universidad de Barcelona, del equipo de Joan Santacana. Con este trabajo se completaba el estudio de la construcción de un museo real, dándole ya el discurso museográfico preciso, que completa al establecido en el anteproyecto ya expuesto, pero acotándolo, realizando un discurso lineal desde la prehistoria al siglo XX. 


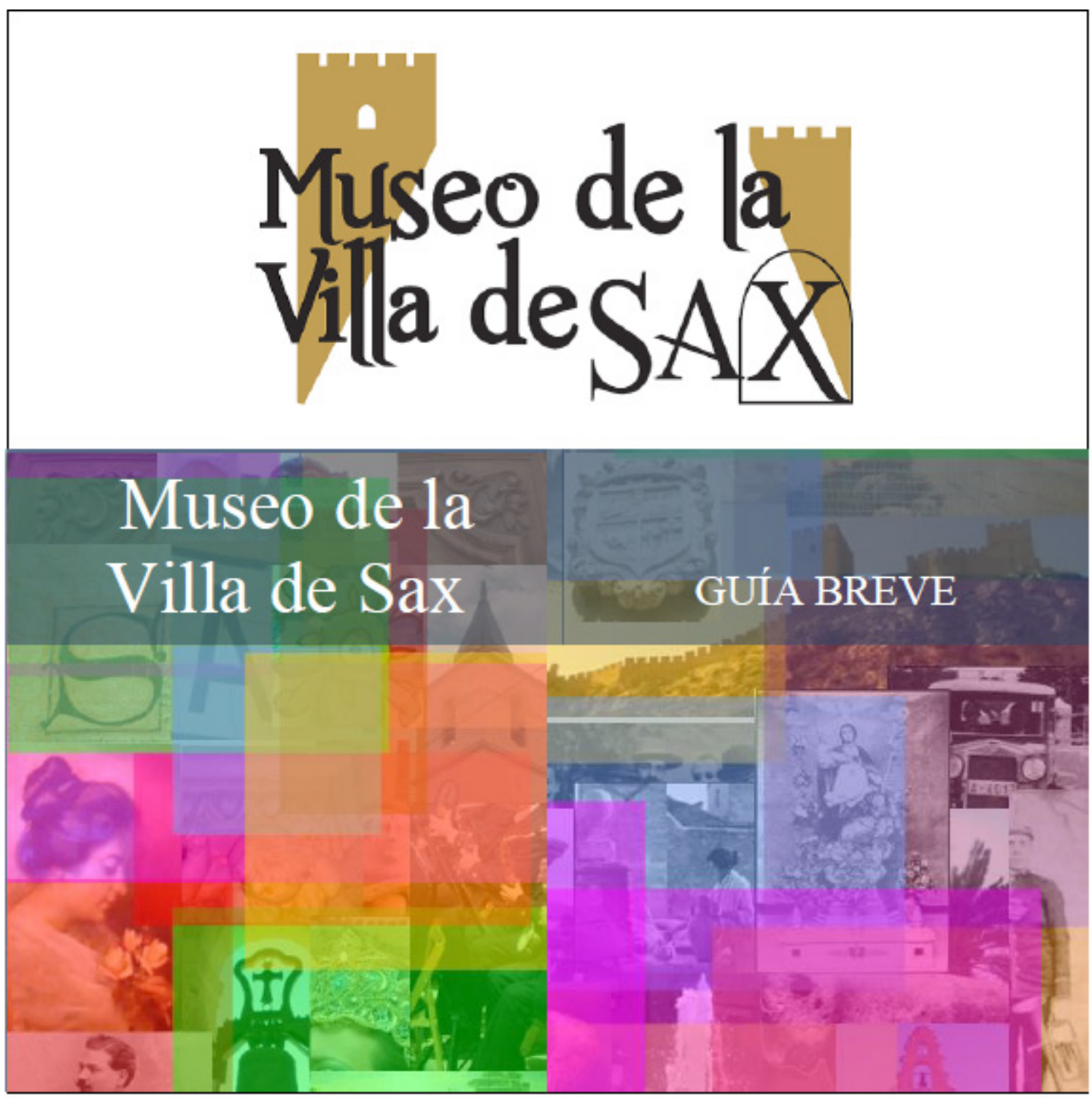

Fig. 7. Proyecto de la portada de la guía breve del Museo de la Villa de Sax. Proyecto básico museológico. Elaboración propia

Un aspecto interesante fue el desarrollo de todos los elementos interactivos que se encontrarían dentro del discurso. La interactividad comenzaría ya fuera del edificio con lo que hemos denominado como ventanas interactivas, unas ventanas con lamas triangulares con la contraposición de dos imágenes u que harían que el museo cambiara de aspecto, dependiendo de la dirección en la que venga el visitante.

Para el desarrollo en la primera planta del museo de la oficina de turismo y centro de recepción de visitantes se establece aquí un discurso con el protagonismo de una "crus de Bienvenida" con una copia digitalizada y restaurada de la cruz de término de Sax y que en cada cara del monumento se escribiría la palaba "Bienvenidos" en distintos idiomas. En esta primera sección también se encontrarían unas consolas con pantallas táctiles e impresoras con guías denominadas "Conoce Sax", "Disfruta Sax" y "Vive Sax".

Un elemento interesante sería la utilización del suelo también como espacio expositivo. En él se expondrían, principalmente, planos y mapas, ya que estos están efectuados para verse en plano, 
utilizándolos para que el visitante sitúe y se sitúe en el tiempo y en el espacio y localice de donde proceden las piezas expuestas en el museo. Otro elemento destacable sería la integración en el discurso expositivo de la escalera de acceso a las salas, desarrollando "La escalera del tiempo", con las fechas representativas de la historia de Sax y con personajes, en las paredes, protagonistas de esos acontecimientos.

Dentro del discurso expositivo hay una serie de elementos que destacan en el diseño. Por ejemplo, la utilización del gran banco de imágenes de finales del siglo XIX y principios del XX que posee el Ayuntamiento se expondría en varias pantallas que, temáticamente, irían mostrando las fotografías. También podemos destacar el diseño de dos maquetas interactivas, realizado por Maquetas Arsanz, y que se referirán al castillo y a la Iglesia de Ntra. Sra. de la Asunción, donde la segunda permitiría también la musealización de los toques de las campanas. Otro aspecto destacado es el de las imágenes. Ya hemos destacado algunos ejemplos, pero hay un caso que denominamos como fotografías parlantes, que hará referencia a los principales representantes de la sociedad sajeña de la segunda mitad del siglo XIX, quienes contarán, a través de un programa de animación, como bustos parlantes, cosas sobre Sax y su época. Aquí dejo un enlace para que se vea el proyecto que se efectuó.

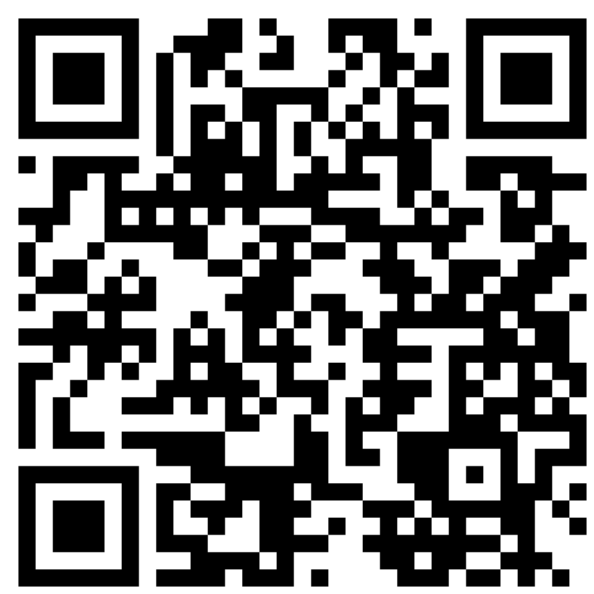

Fig. 8. Proyecto interactivo "Los Caciques de Sax". Elaboración propia

Un aspecto interesante en el montaje expositivo es la posibilidad de acercar al visitante a las piezas a través del juego de interactivos que hemos denominado como "El detalle revelado". Con la utilización de distintos juegos de lupas, y con la indicación de distintas pistas, se pretende que el visitante encuentre distintos elementos tanto en documentos, piezas o fotografías.

En total se han establecido unos 40 puntos interactivos que convertirían al museo en un potente centro, donde cada visitante podría efectuar su propio discurso, utilizando al museo tanto como centro de estudios como centro de esparcimiento o diversión, dependiendo de sus necesidades.

Una vez presentados los tres proyectos, se han desarrollado también ciertos aspectos para presentarlos en congresos, con tal de desarrollar el proyecto, darle presencia y el reconocimiento del resto de profesionales. Así, se presentó el proyecto dentro del ciclo de "Gestión del patrimonio y desarrollo turístico" de la Universidad de Alicante, al igual que la parte de interactividad y de la repercusión en el desarrollo de la gestión del patrimonio sajeño en las Jornadas de Arqueología de la Comunidad Valenciana, en el 2012 y 2014, desarrolladas por el CEL Alicante. Del mismo modo, se habló sobre la repercusión que tendría el proyecto en el desarrollo local de Sax en el IX Coloquio Nacional de Desarrollo Local, en el 2013, además de presentarse el proyecto básico museológico en el II Encuentro Iberoamericano de Gestión del Patrimonio en el mismo año.

\section{EL MUSEO VIRTUAL DE LA VILLA DE SAX}

Con todo este desarrollo del proyecto del Museo de la Villa de Sax ya se habían presentado las características que iba a tener el proyecto en relación a Sax, ya se conocía el modelo de museo que se necesitaba, pero ahora debíamos establecer un diálogo con los sajeños con tal de ver el museo que ellos querían. Ese fue el objetivo del nuevo paso del proyecto, el Museo Virtual de la Villa de Sax, www.museodelavilladesax.wordpress.com. Por ello, hace dos años, 2014, abrimos este blog donde dar a conocer todo el proyecto, además de todas las investigaciones y noticias referentes al patrimonio de la Villa de Sax. 


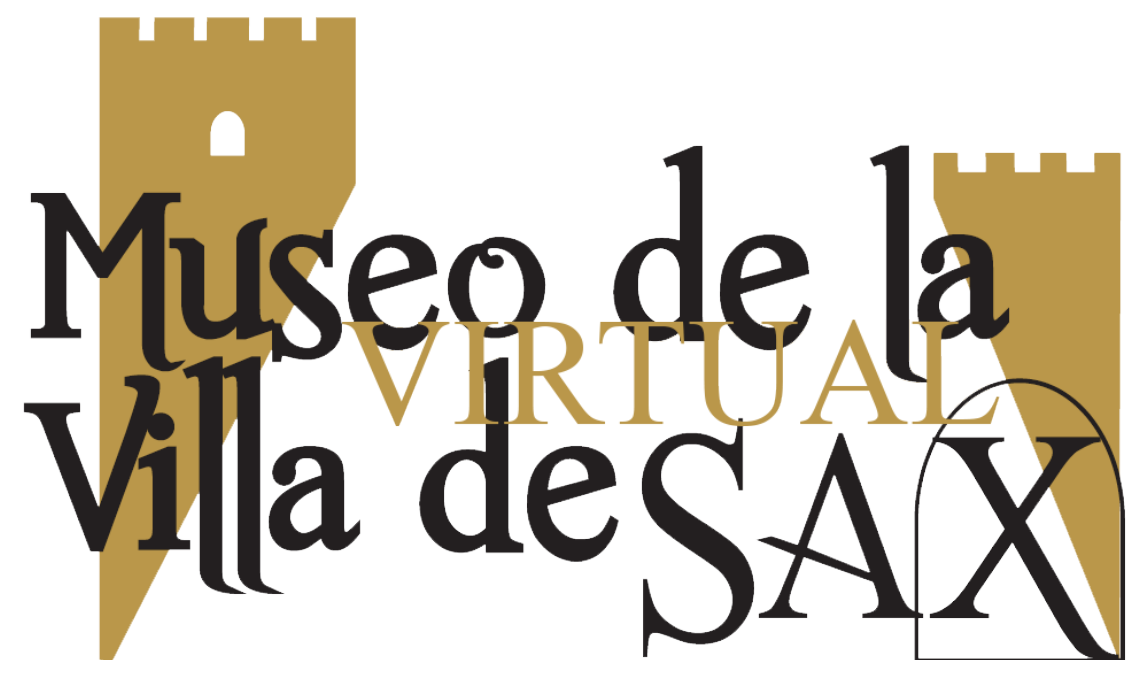

Fig. 9. Logotipo de Museo Virtual de la Villa de Sax, sucesor del anteproyecto museográfico. Elaboración. Antonio Andrés Lorente y Juli Poveda.

El blog ya ha alcanzado cerca de los 50.000 visitantes de todo el mundo. Está compuesto por secciones donde exponemos piezas, elementos del patrimonio, tanto existente como desaparecido y en peligro de extinción, moda, historia del arte, etnografía o arqueología. Además hemos desarrollado varias secciones participativas como el "Banco de imágenes sajeñas", donde los visitantes van enviando sus fotografías de Sax y se van publicando, un espacio dedicado a la castellología y otro a los museos.

Destacaremos que es un blog multiplataforma, por asíllamarlo, ya que unido a este se ha desarrollado un blog de un personaje virtual relacionado con el personaje real de Artal de Alagón, además de un blog de "Museos de la Provincia de Alicante", dentro de la página web del MARQ, además de otro blog de "Patrimonio, Arqueología y museos" en el diario Información. Todo unido a mi web personal, www.ochoagarciaalberto.es.

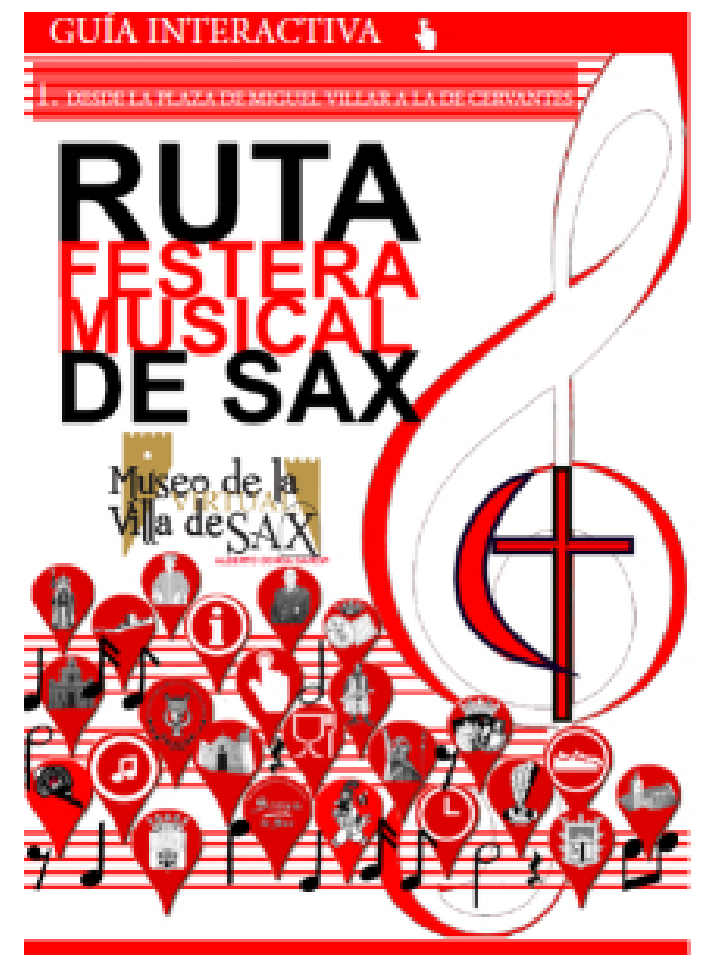

Fig. 10. Ejemplo de publicación del Museo Virtual de la Villa de Sax. Guía Interactiva Ruta Festera Musical de Sax. Elaboración propia.
Un aspecto importante es que a través del Museo de la villa de Sax hemos desarrollado varias publicaciones interactivas, para activarlas en un PC, tablet o Smartphone. Primero desarrollamos la revista del Museo de la Villa de Sax, que va a ser bianual. El primer número lo publicamos en el 2015 y en él, además de leer y ver imágenes, se pueden activar enlaces a contenidos extras o activar vídeos y audios. Las mismas características tiene la Guía Interactiva Ruta Festera musical de Sax, donde se ha desarrollado la función de centro de visitantes de un museo, efectuando una ruta interactiva que guía al visitante pero también le expone las pistas musicales o vídeos de desfiles o piezas destacadas del folclore sajeño. También hemos 
desarrollado otras publicaciones como un cómic de la muerte de Artal de Alagón o un calendario de festividades sajeñas.

\section{CONCLUSIONES. UN MUSEO PARA SAX}

El anteproyecto museográfico del Museo de Historia de Sax ha evolucionado. Desde esas primeras líneas escritas dentro de este máster ha evolucionado hacia un proyecto básico museológico y museográfico, para ahora encontrarse en una forma de Museo Virtual de la Villa de Sax.

Todo este proceso ha servido para entender la necesidad de que Sax disponga de un centro museístico para gestionar adecuadamente todos sus elementos patrimoniales. Custodiar, conservar, exponer, investigar y difundir nuestro patrimonio serían nuestras funciones principales, pero también reactivar el patrimonio, dinamizar el turismo y la cultura, proteger el patrimonio, atraer al público y, sobre todo, participar en el desarrollo local de la población. Todo esto sería lo que se efectuaría desde el Museo de la Villa de Sax. Esperemos que pronto podamos dar el paso definitivo hacia la construcción del museo que Sax necesita y que quieren los sajeños. Mientras tanto, no podemos olvidar que el Museo de la Villa de Sax se encuentra en las principales redes sociales, tanto Facebook, Twitter, Instagram, Youtube como en el blog principal, www.museodelavilladesax.wordpress.com. Entre todos podemos conseguir que el proyecto se haga realidad, siguiendo y apoyando el proyecto.

\section{BIBLIOGRAFÍA}

Alonso Fernández, L., 1999. Museología y museografía. Ediciones del Aguazul.

Azuar Ruiz, R. (2000). Museos alicantinos ante el año 2000. El Museo Arqueológico y la Galería Provincial de Bellas Artes. Canelobre, Revista del Instituto Alicantino de Cultura "Juan Gil-Albert". № 41-42.

Buendía Muñoz, A. (2008). La barrilería: el Museo Provincial de la Uva de Barco (Terque). Boletín del Instituto Andaluz de Patrimonio Histórico. 54-55.

Carpio Dueñas, J.B. (2004). Torredonjimeno. Tesoro, monarquía y liturgia. Exposición temporal en el Museo Arqueológico y Etnológico de Córdoba.Arqueología, proyectos y regeneración urbana. MUS-A. Revista de las instituciones del patrimonio histórico de Andalucía.

Chinchilla Gómez, M. (2005). Criterios para la elaboración del plan museológico. Madrid. Ministerio de Cultura, Subdirección de Bellas Artes y Bienes Culturales, Subdirección General de Museos Estatales.

García Cano, J. M. (2005). El museo de la
Universidad de Murcia. Revista de Museología. Edita Asociación Española de Museólogos. № 3334.

Gil Navarro, J. (2008). Los orígenes de los moros y cristianos en Sax. Sax en la segunda mitad del siglo XIX, la modernización de una sociedad rural. Centro de Estudios y Archivo Histórico Municipal Alberto Sols-CEAHM. Concejalía de Cultura Ilmo. Ayuntamiento de Sax. Col. Picayo, no 1 .

Giménez Gómez, A. (2008). La viticultura y la exportación de vinos como motor del desarrollo económico. Sax en la segunda mitad del siglo XIX, la modernización de una sociedad rural. Centro de Estudios y Archivo Histórico Municipal Alberto Sols-CEAHM. Concejalía de Cultura Ilmo. Ayuntamiento de Sax. Col. Picayo, noㅜ 1 .

Hellín Ferriz, A. (2008). La época del caciquismo. Sax en la segunda mitad del siglo XIX, la modernización de una sociedad rural. Centro de Estudios y Archivo Histórico Municipal Alberto Sols-CEAHM. Concejalía de Cultura Ilmo. Ayuntamiento de Sax. Col. Picayo, no 1.

Hernández Hernández, F. (1994). Manual de museología. Editorial Síntesis. 
Hernández Pérez, M. S. y Pérez Burgos, J. M. (2005). En busca de nuestros orígenes. El poblamiento prehistórico de Sax. Historia de Sax. Edita Comparsa de Moros-Sax.

Jaén González, J., Lillo Flores, E. y Sánchez Reyes, R. (2005). La Colonia de Santa Eulalia. Historia de Sax. Edita Comparsa de Moros-Sax.

Linares Esteve, A. (2008). La llegada del ferrocarril. Sax en la segunda mitad del siglo XIX, la modernización de una sociedad rural. Centro de Estudios y Archivo Histórico Municipal Alberto Sols-CEAHM. Concejalía de Cultura Ilmo. Ayuntamiento de Sax. Col. Picayo, no 1 .

Llopis Hernánez, V. (2008). La pintura de la segunda mitad del siglo XIX en Sax. Sax en la segunda mitad del siglo XIX, la modernización de una sociedad rural. Centro de Estudios y Archivo Histórico Municipal Alberto Sols-CEAHM. Concejalía de Cultura Ilmo. Ayuntamiento de Sax. Col. Picayo, no 1 .

Martínez Castillo, A. (2005). La Primitiva y la Moderna 18887-1930. Sociedad Unión Musical y Artística de Sax 1929-2004. Edita Sociedad Unión Musical y Artística de Sax.

Ochoa García, A. (2009). Pedro Estevan Alpañés: un maestro músico y ebanista para la sociedad sajeña de la segunda mitad del siglo XIX. El Castillo de Sax. Edita Asociación de Estudios Sajeños- Amigos de la Historia de Sax.

Ochoa García, A. (2014). La red de museos locales de Alicante (España) como herramienta básica para la gestión del patrimonio. Espacios, imaginario y gestión del patrimonio. Universidad de Alicante, Universidad Autónoma Metropolitana - Xochimilco. Pp. 245 - 261

Poveda Navarro, A. M. (2009). La escultura del toro de el Chorrillo y el inicio de la iberización del interior del Vinalopó (ss. VI-V a.C.). El mundo antiguo en Sax. Centro de Estudios y Archivo Histórico Municipal Alberto Sols-CEAHM. Concejalía de Cultura Ilmo. Ayuntamiento de Sax. Col. Picayo, no 2 .
Peidró Blanes, J. (2009). “El dinero en tiempos de los romanos. Las monedas antiguas en Sax". El mundo antiguo en Sax. Centro de Estudios y Archivo Histórico Municipal Alberto Sols-CEAHM. Concejalía de Cultura Ilmo. Ayuntamiento de Sax. Col. Picayo, no 2 .

Pérez Amorós, L. (2005). Prospecciones arqueológicas en la mitad oriental. Historia de Sax. Edita Comparsa de Moros-Sax.

Requejo, A., Mascarell, M., Parés, N. (2009). Descubriendo el patrimonio a través de la comunicación interactiva. Revista de Museología. Edita Asociación Española de Museólogos. no 44.

Santacana Mestre, J. y Serrat Antolín, N. (coord.), (2005). Museografía didáctica. Editorial Ariel, S. A.

Sarrió Martínez, A. (2006). La trilla en Sax. Edita Asociación de Estudios Sajeños- Grupo Amigos de la Historia de Sax.

Soler Díaz, J. A. y Castells González, R. M. (Coord.) (2000). Los museos de Alicante. Canelobre, Revista del Instituto Alicantino de Cultura "Juan Gil-Albert". № 41-42.

Tendero Fernández, F. E. (2005). Sax islámico. Historia de Sax. Edita Comparsa de Moros-Sax.

Vázquez Hernández, V. (2005). La música en Sax durante los siglos XVI-XIX. Sociedad Unión Musical y Artística de Sax 1929-2004. Edita Sociedad Unión Musical y Artística de Sax.

Código Deontológico del ICOM para Museos, 2006 (http://icom.museum/codigo.html)

Ley 4/1998 del 11 de junio, de la Generalitat Valenciana, del Patrimonio Cultural Valenciano. (http://noticias.juridicas.com/base datos/ CCAA/va-14-1998.html)

Orden de 6 de Febrero de 1991, de la Conselleria de Cultura, Educación y Ciencia. Diari Oficial 1494 de 28.02.1991. 